\title{
EVALUATING THE IMPLEMENTATION OF BCA MOBILE BANKING USING HOT-Fit MODEL
}

\author{
Hartanto Michaela*, Student \\ Permana Gusi Putu Lestara, Lecturer \\ Pendidikan Nasional University, Bali, Indonesia \\ *E-mail: michaelahartanto98@gmail.com
}

\begin{abstract}
BCA Mobile Banking, well-known as BCA Mobile has become a valuable tool for conducting financial transactions and for obtaining financial information. Apart from the potential benefits of BCA Mobile Banking, its adoption remains a challenge because traditional transactions through BCA branch offices, visiting ATMs, and the use of internet banking are more dominant among Indonesian people. The purpose of this study is to evaluate the implementation of BCA Mobile Banking and its net benefits for individuals in Denpasar, Bali using the Human Organization Technology Fit (HOT-Fit) Model. Data were collected from 70 respondents in the Denpasar area, Bali, Indonesia. Data were analyzed using the Partial Least Squares (PLS) method, a statistical analysis technique based on Structural Equation Modelling (SEM). This study found that system quality, information quality, and service quality have a significant positive impact on system use and user satisfaction for using BCA Mobile Banking. In addition, system use, user satisfaction and organization structure have a significant positive impact on net benefits. The findings of this study can be used by other banks that have mobile banking products to maximize the adoption of the use of mobile banking and support the creation of a cashless society in Indonesia.
\end{abstract}

\section{KEY WORDS}

Bank Central Asia, D\&M IS success model, human organization technology fit model, information system, MIT90s, organizational fit model, partial least square.

Information technology becomes the most important part to support the lives of millennials. The rapid development of information technology has changed many people's lifestyles from conventional to modern. For instance, in communication: the presence of technology makes information dissemination wider and easier through the internet, in transportation: now many people prefer to use online transportation rather than offline transportations, and in finance: technological advances has made a big change in the banking industry where the bank has been transformed from a provider of paper-based banking solutions to the latest technology (Oswari and Prasetyo 2019). The massive change in the banking world is also one of an attempt from Indonesian government to create a cashless society as a culture in both conducting a transaction and obtaining financial information. This is an opportunity for banks to move forward by providing better services for their customer. They are not only offering speed but also comfort and convenience without requiring customer to come and queue at ATM or Bank's branch offices. This easiness and convenience are offered by bank through mobile banking service (Angela 2014). The mobile banking facility can answer the demands of customers who want fast, safe, comfortable, inexpensive and available services at any time and can be accessed from anywhere, through a cell phone.

In Indonesia, both state and private banks are competing with each other to launch their mobile banking services. According to (Putriansyah 2015), Bank Central Asia (BCA) as one of a largest private bank in Indonesia, is the first bank that launches the mobile banking system in Indonesia for its customers. The mobile banking product offered by BCA is BCA Mobile which can be used by anyone who has a BCA ATM card except for the customers who use "Tahapanku" category they cannot use mobile banking because this category is not 
intended for children. The features found in m-banking m-BCA consist of m-info, m-transfer, m-payment, m-commerce, m-admin, and cash withdrawal (BCA 2019).

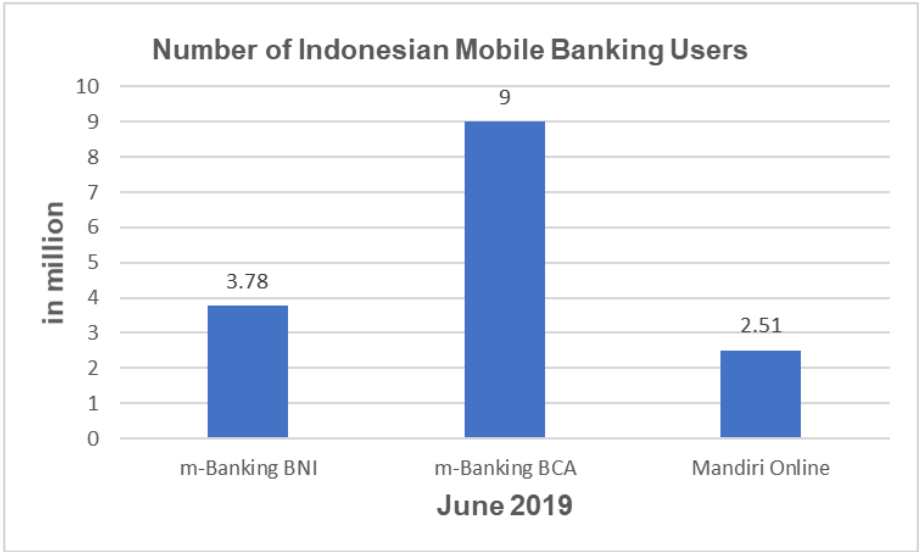

Figure 1 - Number of Indonesian Mobile Banking Users (Source: Sitanggang, 2019)

The data above shows that Mandiri m-Banking / Mandiri Online users are 2.51 million, followed by BNI m-Banking with 3.78 million users, and BCA's m-Banking occupies the first position with 9 million users. It can be concluded that the majority of mobile banking users in Indonesia use BCA Mobile.

Although BCA Mobile has been widely used by Indonesians, it turns out that the total value of BCA m-banking transactions is still lower than transactions at branch offices, ATMs and Internet Banking. In addition, apart from many benefits gained by customers in using mobile banking, many BCA Mobile users complained about various problems related to the BCA Mobile feature. They were considered to be less user friendly, sometimes there was an error with the application, and there were some BCA customers who could not log in into BCA Mobile (Sanusi 2019; Sukmana 2019). The President Director of BCA also confirmed that the BCA Mobile was quite often experiencing errors and BCA had tried their best to normalize it again (Franedya 2019).

One of the model theories to analyze the success level of system is HOT-Fit model developed by (Yusof, Paul, and Stergioulas 2006). This model is considered capable of explaining the evaluation of the success of a system in a comprehensive approach to the components of human, organization, and technology as well as the suitability of the three components and influencing the net benefits of implementing the information system (Kodarisman and Nugroho 2013). This evaluation model clarifies all the components contained in the information system itself, namely Human who assesses the information system from the user's system (system use) and user satisfaction, Organizations that assess a system from the organizational structure and organizational environment and, Technology that evaluates system quality, information quality, and service quality (Poluan, Lumenta, and Sinsuw 2014). Therefore, this research used Human-Organization-Technology Fit Model to evaluate a system that includes important components of an information system, namely Human, Organization Technology to evaluate the success level of BCA Mobile application from BCA.

\section{LITERATURE REVIEW}

Human Organizational Technology (HOT) Fit model is a theoretical model developed by (Yusof, Paul, and Stergioulas 2006) that combine two models theories, which are IS Success Model (Delone and Mclean 1992; 2003) and IT Organizational Fit Model (Morton 1991). He states that the HOT-Fit framework model could be used to evaluate the performance, effectiveness and impact of the information system. HOT-Fit address the essential components of IS, namely human, organization and technology and the fit between them. According to (Krisbiantoro, Suyanto, and Taufiq Luthfi 2015) HOT-Fit model is a 
complete and most appropriate model with the existing problem conditions compared to other models because the HOT-Fit model accommodates organizational structure and environment variables where the variable does not exist in the previous models.

Previous research states that system quality is the performance of the system which refers to how well the capabilities of the hardware, software, policies, procedures of the information system can provide user information needs (Delone and Mclean 1992). Prior research defines information quality as a data that has been converted into meaningful and useful information for certain users (O'Brien 2005). Service quality can be interpreted as user perception of an application of the quality of services provided by the software implementer team (Jiang, Klein, and Carr 2002). According to prior study conducted by (Robbins and Coulter 2007) states that the organizational structure can be interpreted as a formal organizational framework within which the work tasks are divided, grouped, and coordinated. System use is the level and manner in which users utilize the capabilities of an information system (DeLone and McLean 2016). According to (Gunawardena 2017), user satisfaction is a user's feelings by comparing the services and results provided according to expectations. Net benefits are the result of using information systems that contribute to individuals, groups and organizations (Delone and Mclean 2003).

BCA mobile banking is a mobile banking application offered by Bank Central Asia in Indonesia to provide easy transactions and to obtain financial information for its customers. Customers can make transactions both financial and non-financial wherever and whenever only through smartphones. Various services are available on the BCA Mobile application, which can be downloaded for free on the Google Play store or AppStore, which are the Open New Account, QRku, Chatting Facility, BCA ATM Card Blocking Facility, BCA Credit Card Blocking Facility, Credit Card Control Facility, BCA Credit Card Activation Facility, Facility to Make / change BCA Credit Card PIN, Cardless Transaction Facility, BCA Credit Card eStatement Check Facility, BCA Credit Card Limit Request Facility, and BCA Reward Check Facility (BCA 2019).

Hypotheses:

$\mathrm{H1}$ : System quality has a positive effect on system use of BCA Mobile Banking;

H2: System Quality has a positive effect on User Satisfaction of BCA Mobile Banking;

H3: Information Quality has a positive effect on System Use of BCA Mobile Banking; Banking;

H4: Information Quality has a positive effect on User Satisfaction of BCA Mobile

H5: Service Quality has a positive effect on System Use of BCA Mobile;

H6: Service Quality has a positive effect on User satisfaction of BCA Mobile;

H7: System use has a positive effect on Net benefits of BCA Mobile;

H8: User Satisfaction has a positive effect on Net benefits of BCA Mobile;

H9: Organization Structure has a positive effect on Net benefits of BCA Mobile.

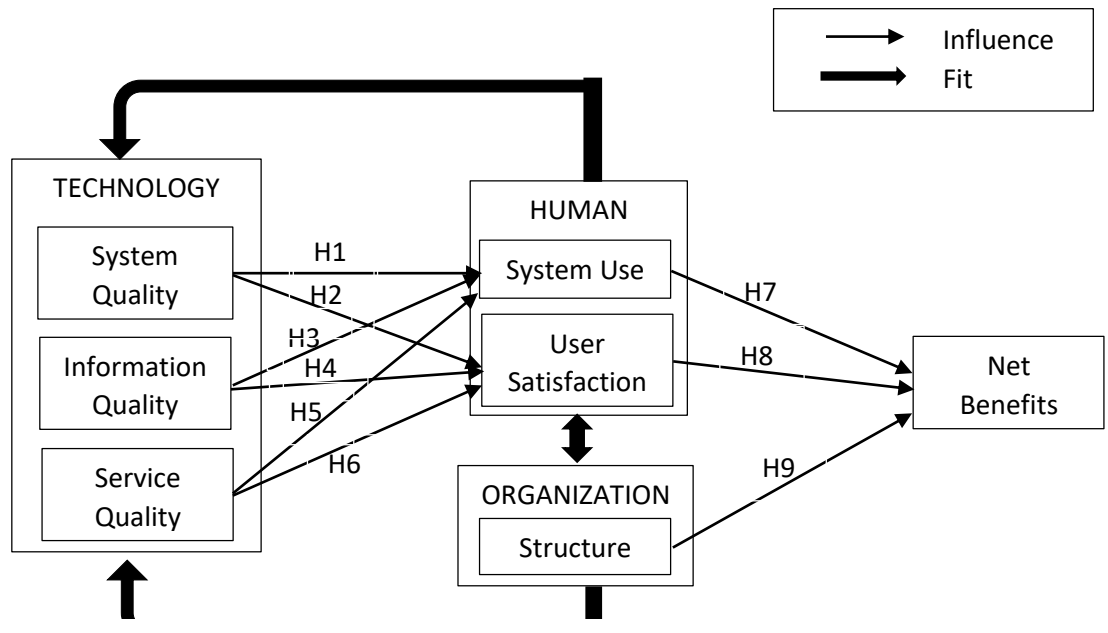

Figure 2 - The proposed research framework 


\section{METHODS OF RESEARCH}

This research was conducted in Denpasar city because Denpasar city was the capital of the province of Bali, the center of economic activity, the center of government and the center of banking operations in Bali (Bank Indonesia 2019). In addition, Denpasar city has the most BCA branch offices in Bali compared to other Bali regions. This research uses quantitative data. The data used are classified as primary data, where the data is obtained through the distribution of questionnaires to respondents who meet the criteria. Criteria for respondents in this study are BCA bank customers who reside in the city of Denpasar and use BCA Mobile to transact at least once.

In accordance with the explanation in the book "A Primer on Partial Least Squares Structural Equation Modeling (PLS-SEM)", (Hair; et al. 2013) states that the minimum sample size using PLS-SEM is 10 times the number of variables in the structural measurement model or formative. Therefore, the number of samples in this research were 70 people who live in Denpasar city and use BCA Mobile at least once using the purposive sampling method. According to (Sugiyono 2016), purposive sampling is a sampling technique for data sources with certain considerations.

The statistical testing method uses Partial Least Square (PLS). PLS analysis is a multivariate statistical technique that makes comparisons between multiple dependent variables and multiple independent variables. PLS is one of the variant-based SEM statistical methods that is designed to solve multiple regressions when specific problems occur in data, such as small sample sizes, missing data and multicollinearity(Hartono and Abdillah 2016). Data analysis using PLS was assisted with SmartPLS software version 2.0 M3.

\section{RESULTS AND DISCUSSION}

Respondents in this research were BCA customers who live in Denpasar city and use BCA Mobile to make financial and non-financial transaction at least once. The characteristic respondents in this study were dominated by men as much as $62.9 \%$ with the most dominant age range of $25-30$ years. In addition, in this study $50 \%$ of the total respondents lived in south Denpasar.

This research was tested using validity and reliability tests to determine the ability of research instruments to measure certain variables and to measure the level of consistency of respondents' answers and the validity of the questionnaire in this study

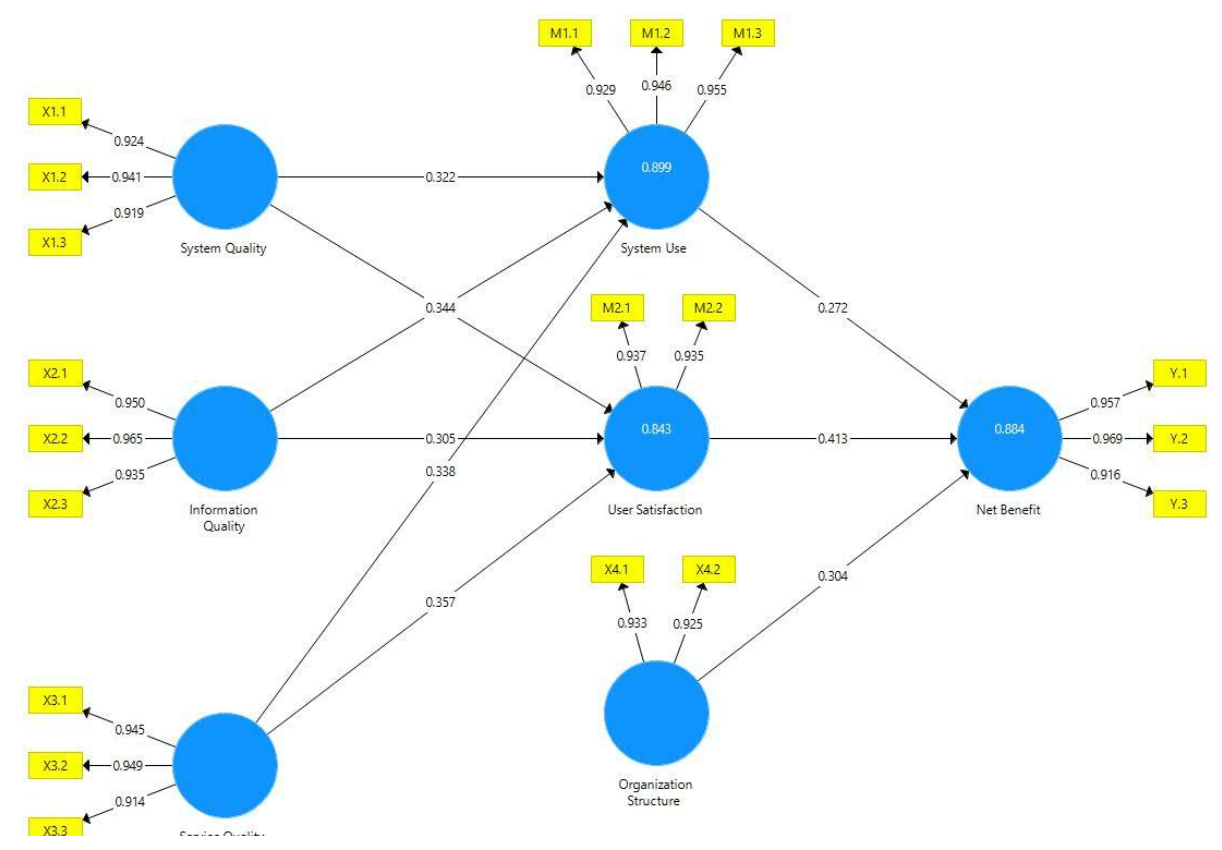

Figure 3 - Measurement Model (Outer Model) 
Table 1 - Loading Factor Results

\begin{tabular}{|c|c|c|c|c|c|}
\hline Construct & Indikator & LF & Construct & Indikator & $\mathrm{LF}$ \\
\hline \multirow{3}{*}{$\begin{array}{l}\text { System } \\
\text { Quality }\end{array}$} & SyQ1 & 0,924 & \multirow{2}{*}{\begin{tabular}{|c|} 
Organization \\
Structure \\
\end{tabular}} & OS1 & 0,933 \\
\hline & SyQ2 & 0,941 & & OS2 & 0,925 \\
\hline & SyQ3 & 0,919 & \multirow{3}{*}{ System Use } & SU1 & 0,929 \\
\hline \multirow{3}{*}{$\begin{array}{c}\text { Information } \\
\text { Quality }\end{array}$} & IQ1 & 0,950 & & SU2 & 0,946 \\
\hline & IQ2 & 0,965 & & SU3 & 0,955 \\
\hline & IQ3 & 0,935 & \multirow{2}{*}{\begin{tabular}{c|} 
User \\
Satisfaction
\end{tabular}} & US1 & 0,937 \\
\hline \multirow{3}{*}{$\begin{array}{l}\text { Service } \\
\text { Quality }\end{array}$} & SQ1 & 0,945 & & US2 & 0,935 \\
\hline & SQ2 & 0,949 & \multirow{3}{*}{ Net Benefits } & NB1 & 0,957 \\
\hline & SQ3 & 0,914 & & NB2 & 0,969 \\
\hline & & & & NB3 & 0,916 \\
\hline
\end{tabular}

Based on table 1, it can be seen the value of each score item / indicator of each variable System Quality (SyQ), Information Quality (IQ), Service Quality (SQ), System Use (SU), User Satisfaction (US), Organization Structure (OS) and Net Benefits (NB) have values greater than 0.5 , therefore, all indicators are considered to be valid.

Table 2 - Cross Loading between Indicator and Construct

\begin{tabular}{|c|c|c|c|c|c|c|c|}
\hline & $\begin{array}{c}\text { formation Qual } \\
\left(\mathrm{X}_{2}\right)\end{array}$ & $\begin{array}{c}\text { Net Benefits } \\
\text { (Y) }\end{array}$ & $\begin{array}{c}\text { anization Struc } \\
(\mathrm{X} 4)\end{array}$ & $\begin{array}{c}\text { Service Qualit } \\
\text { (X3) }\end{array}$ & \begin{tabular}{|c|} 
System Qualit \\
(X1)
\end{tabular} & $\begin{array}{c}\text { System Use } \\
\text { (M1) }\end{array}$ & $\begin{array}{c}\text { ser Satisfactio } \\
\text { (M2) }\end{array}$ \\
\hline M1.1 & 0,805 & 0,839 & 0,726 & 0,836 & 0,841 & 0,929 & 0,825 \\
\hline M1.2 & 0,832 & 0,818 & 0,728 & 0,842 & 0,816 & 0,946 & 0,827 \\
\hline M1.3 & 0,864 & 0,812 & 0,747 & 0,889 & 0,874 & 0,955 & 0,84 \\
\hline M2.1 & 0,799 & 0,868 & 0,808 & 0,836 & 0,818 & 0,826 & 0,937 \\
\hline M2.2 & 0,794 & 0,851 & 0,829 & 0,817 & 0,806 & 0,823 & 0,935 \\
\hline $\mathrm{X} 1.1$ & 0,778 & 0,817 & 0,715 & 0,834 & 0,924 & 0,817 & 0,849 \\
\hline $\mathrm{X} 1.2$ & 0,746 & 0,814 & 0,724 & 0,816 & 0,941 & 0,851 & 0,803 \\
\hline $\mathrm{X} 1.3$ & 0,705 & 0,758 & 0,701 & 0,792 & 0,919 & 0,822 & 0,761 \\
\hline $\mathrm{X} 2.1$ & 0,95 & 0,771 & 0,679 & 0,79 & 0,775 & 0,842 & 0,81 \\
\hline $\mathrm{X} 2.2$ & 0,965 & 0,808 & 0,721 & 0,814 & 0,793 & 0,856 & 0,833 \\
\hline $\mathrm{X} 2.3$ & 0,935 & 0,765 & 0,726 & 0,771 & 0,716 & 0,822 & 0,782 \\
\hline $\mathrm{X} 3.1$ & 0,806 & 0,836 & 0,735 & 0,945 & 0,863 & 0,877 & 0,847 \\
\hline $\mathrm{X} 3.2$ & 0,786 & 0,771 & 0,679 & 0,949 & 0,825 & 0,859 & 0,799 \\
\hline $\mathrm{X} 3.3$ & 0,747 & 0,763 & 0,709 & 0,914 & 0,774 & 0,81 & 0,833 \\
\hline $\mathrm{X} 4.1$ & 0,703 & 0,835 & 0,933 & 0,721 & 0,713 & 0,728 & 0,814 \\
\hline $\mathrm{X} 4.2$ & 0,682 & 0,794 & 0,925 & 0,684 & 0,716 & 0,717 & 0,81 \\
\hline Y.1 & 0,81 & 0,957 & 0,828 & 0,806 & 0,82 & 0,856 & 0,878 \\
\hline Y.2 & 0,783 & 0,969 & 0,881 & 0,807 & 0,824 & 0,821 & 0,905 \\
\hline 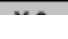 & $n \rightarrow$ & $\ldots$ & $n$ & A & 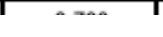 & $\sim \ldots$ & $n \operatorname{san}$ \\
\hline
\end{tabular}

Based on the table 2, it can be viewed that all the cross-loading values of each indicator on each variable are greater than 0.7 . Thus, it can be stated that the data in the study are valid.

Table 3 - Construct Reliability Results

\begin{tabular}{|l|l|l|}
\hline \multicolumn{1}{|c|}{$\mathrm{n} / \mathrm{n}$} & Cronbach's Alpha & Composite Reliability \\
\hline Information Quality (X2) & 0,946 & 0,965 \\
\hline Net Benefits (Y) & 0,943 & 0,964 \\
\hline Organization Structure (X4) & 0,841 & 0,926 \\
\hline Service Quality (X3) & 0,929 & 0,955 \\
\hline System Quality (X1) & 0,919 & 0,949 \\
\hline System Use (M1) & 0,938 & 0,96 \\
\hline User Satisfaction (M2) & 0,859 & 0,934 \\
\hline
\end{tabular}

Based on the table 3, it can be seen that all Composite reliability and Cronbach's alpha values in each construct are greater than 0.7 . Thus, it can be stated that the data in the study are reliable. 


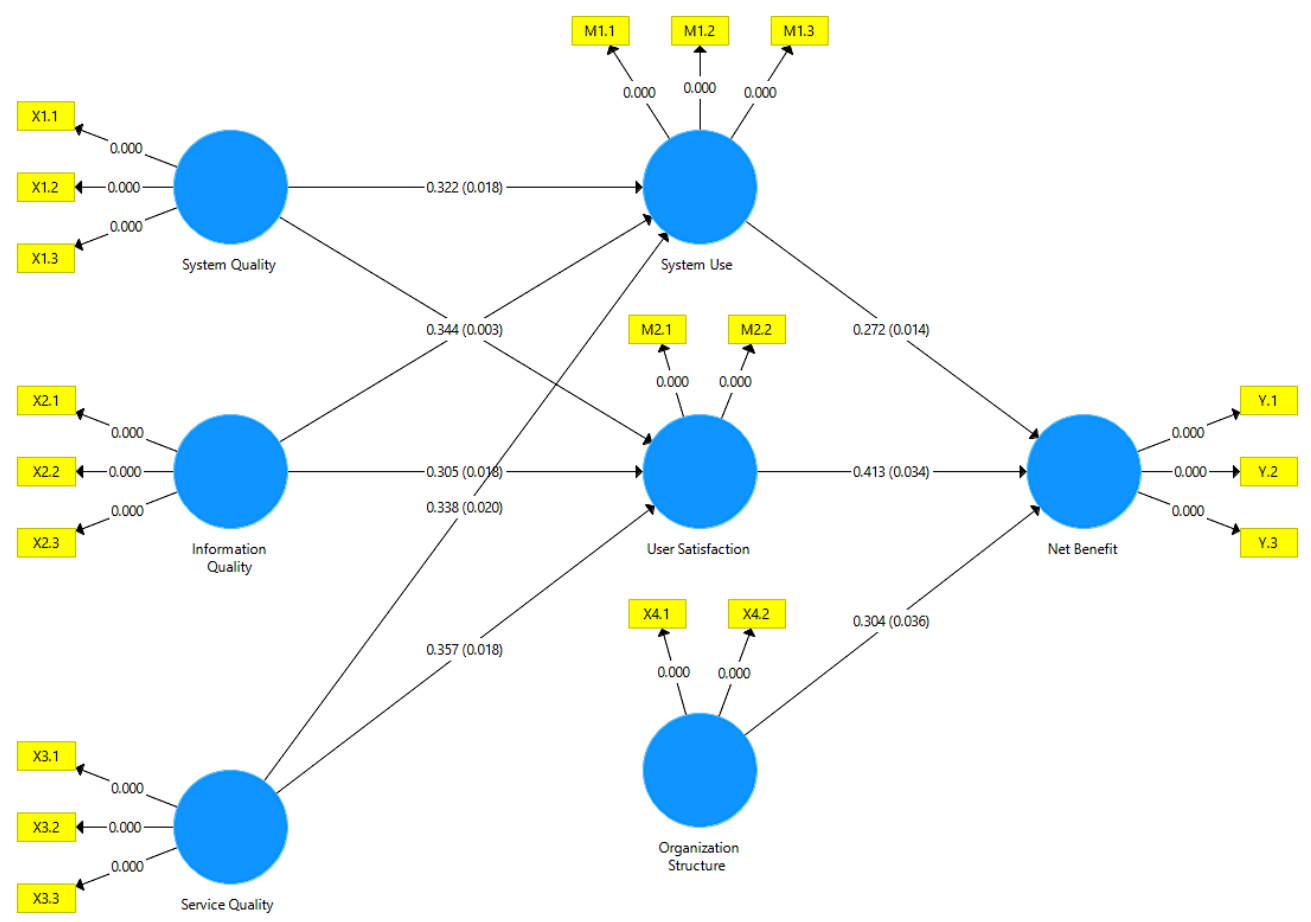

Figure 4 - Inner Model Results

Table $4-R^{2}$ Results

\begin{tabular}{|l|l|l|}
\hline \multicolumn{1}{|c|}{$\mathrm{n} / \mathrm{n}$} & $\mathrm{R}$ Square & Adjusted R Square \\
\hline Net Benefits (Y) & 0,884 & 0,878 \\
\hline System Use (M1) & 0,899 & 0,894 \\
\hline User Satisfaction (M2) & 0,843 & 0,836 \\
\hline
\end{tabular}

It can be seen in the output table above the $R^{2}$ value of System Use is 0,894 based on these results it can be concluded that $89,4 \%$ of System Use is influenced by System Quality, Information Quality, and Service Quality. $R^{2}$ value of User Satisfaction is 0,836 which means that $83,6 \%$ of User Satisfaction is influenced by System Quality, Information Quality, and Service Quality, while the rest is influenced by other variables not used in this study. $R^{2}$ value of Net Benefits is 0,878 which means that $87,8 \%$ Net Benefits is influenced by Organization Structure, System Use, and User Satisfaction, while the rest is influenced by other variables not used in this study.

Table 5 - Path Coefficient Results

\begin{tabular}{|c|c|c|c|c|}
\hline & Original Sample & Sample & T Statistics & \multirow{3}{*}{$\begin{array}{c}\mathrm{P} \\
\text { Values }\end{array}$} \\
\hline & \multirow[t]{2}{*}{ (O) } & Mean & (|O/STERR|) & \\
\hline & & (M) & & \\
\hline System Use (M1) > Net Benefits (Y) & 0,272 & 0,249 & 2,389 & 0,017 \\
\hline User Satisfaction (M2) > Net Benefits (Y) & 0,413 & 0,446 & 2,131 & 0,034 \\
\hline System Quality (X1) > System Use (M1) & 0,322 & 0,314 & 2,32 & 0,021 \\
\hline $\begin{array}{c}\text { System Quality (X1) > User Satisfaction } \\
(\mathrm{M} 2)\end{array}$ & 0,309 & 0,323 & 2,459 & 0,014 \\
\hline $\begin{array}{l}\text { Information Quality (X2) > System Use } \\
(\mathrm{M} 1)\end{array}$ & 0,344 & 0,341 & 2,961 & 0,003 \\
\hline $\begin{array}{c}\text { Information Quality (X2) > User } \\
\text { Satisfaction (M2) }\end{array}$ & 0,305 & 0,294 & 2,37 & 0,018 \\
\hline Service Quality (X3) > System Use (M1) & 0,338 & 0,351 & 2,196 & 0,029 \\
\hline $\begin{array}{c}\text { Service Quality (X3) > User Satisfaction } \\
\text { (M2) }\end{array}$ & 0,357 & 0,355 & 2,288 & 0,023 \\
\hline $\begin{array}{c}\text { Organization Structure }(\mathrm{X} 4)>\mathrm{Net} \\
\text { Benefits }(\mathrm{Y})\end{array}$ & 0,304 & 0,293 & 2,077 & 0,038 \\
\hline
\end{tabular}


Based on the test result shows that the relation between System Quality, Information Quality, and Service Quality with System Use and User Satisfaction shows a significant value with a T statistic value> 1,96. The original sample value System Quality, Information Quality, and Service Quality are positive. Moreover, it shows the relations between System Use, Organization Structure and User Satisfaction with Net Benefits. It can be seen that System Use, User Satisfaction, and Organization Structure has a significant positive impact on Net Benefits with a T statistic value $>1,96$. The hypothesis result is summarized in table 6 .

Table 6 - Hypotheses test results

\begin{tabular}{|l|l|l|l|l|}
\hline Hypotheses & Effect & T-statistic & P-Values & Supported \\
\hline H1 & SyQ > SU & 2,32 & 0,021 & Yes \\
\hline H2 & SyQ > US & 2,459 & 0,014 & Yes \\
\hline H3 & IQ > SU & 2,961 & 0,003 & Yes \\
\hline H4 & IQ > US & 2,37 & 0,018 & Yes \\
\hline H5 & SQ > SU & 2,196 & 0,029 & Yes \\
\hline H6 & SQ > US & 2,288 & 0,023 & Yes \\
\hline H7 & SU > NB & 2,389 & 0,038 & Yes \\
\hline H8 & US > NB & 2,131 & 0,017 & Yes \\
\hline H9 & OS > NB & 2,077 & 0,034 & Yes \\
\hline
\end{tabular}

This research results in accordance with the researches conducted by (Kodarisman and Nugroho 2013; Krisbiantoro, Suyanto, and Taufiq Luthfi 2015; Asnawi 2016; Monalisa, Anggara, and Kurnia 2018; Wibowo 2013) that system quality, information quality, and service quality has a significant and positive effect with system use and user satisfaction. In addition, system use, user satisfaction and organization structure also affect significantly and positively towards net benefits. This means that the respondents believe that BCA Mobile Banking able to help them with their work, easy to use, provide valuable and beneficial information for its user, the services has met the customer's expectation, and they are satisfied. Moreover, this research results shows that BCA Mobile Banking has a good division of labor within the

\section{CONCLUSION}

Based on the results of data analysis discussion on evaluating the implementation of BCA mobile banking in Denpasar City, it can be concluded that:

- The success of the implementation of BCA mobile is influenced by factors of system quality, information quality, service quality, system use, user satisfaction and organizational structure;

- System quality has a positive and significant effect on system use and user satisfaction. This means that the higher the quality of the system at BCA Mobile Banking, the system use and user satisfaction of BCA Mobile will also increase;

- Information quality has a positive and significant impact on system use and user satisfaction. This means that the better the quality of information that can be provided by BCA Mobile Banking, it will increase the system use and user satisfaction;

- Service quality has a positive and significant effect on system use and user satisfaction. This means that the higher the quality of BCA Mobile banking services, the system use and user satisfaction of BCA Mobile Banking will also increase;

- System use has a positive effect and has a strong relationship with net benefits. This means that the higher the system use of BCA mobile banking, the greater the net benefits gained;

- User satisfaction has a positive and significant effect on net benefits. This means that the higher user satisfaction is, the higher the net benefits gained from using BCA Mobile Banking;

- The organizational structure has a positive and significant effect on net benefits. This means that the better the division of labor within the organization, the higher the net benefits gained from using BCA Mobile Banking. 


\section{REFERENCES}

1. Angela, Maya. 2014. "Faktor-Faktor Yang Mempengaruhi Minat Nasabah Menggunakan Internet Banking Pada PT BRI Cabang Ahmad Yani Makassar." Universitas Hasanuddin.

2. Asnawi, S.IP. 2016. "Evaluasi Implementasi Sistem Informasi Senayan Library Management System (Slims) Di Perpustakaan Universitas Syiah Kuala Dengan Menggunakan Human Organization Technology (Hot) Fit Model." Universitas Sunan Kalijaga.

3. Bank Indonesia. 2019. "Laporan Perekonomian Provinsi Bali 2019."

4. BCA. 2019. "BCA." BCA. 2019.

5. DeLone, William H., and Ephraim R. McLean. 2016. "Information Systems Success Measurement." Management Information System 2 (1): 32.

6. Delone, William H, and Ephraim R Mclean. 1992. "Information Systems Success: The Quest for the Dependent Variable." Information System Research 3(1) (August 2015): 60-95.

7. 2003. "Journal of Management The DeLone and McLean Model of Information Systems Success: A Ten-Year Update," no. March 2015: 37-41. https://doi.org/10.1080/07421222.2003.11045748.

8. Franedya, Roy. 2019. "Penjelasan Bos BCA Soal Mobile Banking BCA Error." CNBC Indonesia. 2019.

9. George, B. 2001. A Framework for IT Evaluation Research. Americas Conference on Information Systems. AMCIS 2001. USA.

10. Gunawardena, NK. 2017. "The Impact Of Self-Service Technology On Customer Satisfaction Of Online Stores." International Journal Of Scientific \& Technology Research $6(7): 7$.

11. Hair;, Joseph F., Jr.;, G. Tomas M. Hult;, Christian Ringle;, and Marko Sarstedt. 2013. A Primer on Partial Least Squares Structural Equation Modeling (PLS-SEM). SAGE.

12. Hartono, J., and W. Abdillah. 2016. Konsep and Aplikasi PLS (Partial Least Square) Untuk Penelitian Empiris. BPFE Editi. Yogyakarta: Badan penerbit fakultas ekonomi yogyakarta.

13. Jiang, James J, Gary Klein, and Christopher L Carr. 2002. "Measuring Information System Service Quality: SERVQUAL from the Other Side." MIS Quarterly 26 (2): 145-66.

14. Kodarisman, Raden, and Eko Nugroho. 2013. "Evaluasi Penerapan Sistem Informasi Manajemen Kepegawaian ( SIMPEG ) Di Pemerintah Kota Bogor" 2 (2): 24-32.

15. Krisbiantoro, Dwi, M. Suyanto, and Emha Taufiq Luthfi. 2015. "Evaluasi Keberhasilan Implementasi Sistem Informasi Dengan Pendekatan Hot Fit Model (Studi Kasus: Perpustakaan STMIK AMIKOM Purwokerto)." STIMIK STIKOM BALI 9: 6.

16. Monalisa, Siti, Presdi Ponti Anggara, and Fitra Kurnia. 2018. "Analisis Kesuksesan Penerapan Sistem Administrasi Akademik Menggunakan Human Organization Technology Fit Model." Jurnal IImiah Rekayasa and Manajemen Sistem Informasi 4 (1): 36-41.

17. Morton, Michael S. Scott. 1991. The Corporation of the 1990s. Edited by Lester Thurow. Research S. New York: Oxford University Press.

18. O'Brien, James. 2005. Pengantar Sistem Informasi Perspektif Bisnis Manajerial. Edisi 12. Jakarta: Salemba Empat.

19. Oswari, Teddy, and Yoga Alif Prasetyo. 2019. "The Implementation Of The Human , Organization , And Technology - Fit ( Hot - Fit ) Models To Evaluate The Mobile Banking." International Journal of Economics, Commerce and Management VII (6): 497504.

20. Poluan, Frincy, Arie Lumenta, and Alicia Sinsuw. 2014. "Evaluasi Implementasi Sistem E-Learning Menggunakan Model Evaluasi HOT Fit Studi Kasus Universitas Sam Ratulangi Manado." Jurnal Teknik Informatika 4 (2).

21. Putriansyah, Irna. 2015. "Mengulik Sejarah Mobile Banking." Kreditgogo.Com. 2015. https://kreditgogo.com/artikel/Digital-Banking/Mengulik-Sejarah-Mobile-Banking.html.

22. Robbins, S., and M. Coulter. 2007. Manajemen. 8th Editio. Jakarta: PT Indeks. 
23. Sanusi. 2019. "Layanan Mobile Banking BCA Sempat Tak Bisa Diakses Pada Senin Pagi." Tribunnews.Com. 2019.

24. Sitanggang, Laurensius Marshall Sautlan. 2019. "Transaksi Mobile Banking Perbankan Makin Ramai." Kontan.Co.Id. 2019.

25. Sugiyono. 2016. Metode Penelitian Pendidikan Pendekatan Kuantitatif, Kualitatif, and R\&D. Bandung: Afabeta.

26. Sukmana, Yoga. 2019. "Senin Pagi, Layanan Mobile Banking BCA Sempat Tak Bisa Diakses." Kompas.Com, October 2019.

27. Wibowo, Wendy Ariesta. 2013. "Pengaruh System Quality, Information Quality, and Service Quality Terhadap User Satisfaction Website Lion Airlines and Sriwijaya Airlines." Jurnal Manajemen Pemasaran 1 (22).

28. Yusof, Maryati Mohd, Ray J Paul, and Lampros K Stergioulas. 2006. "Towards a Framework for Health Information Systems Evaluation" 00 (C): 1-10. 